\section{- Contemporary Community}

SOCIOLOGICAL ILLUSION OR REALITY?

\section{JACQUELINE SCHERER}

A critical examination, based on original research and published studies, of the myth and reality of community in the modern world.

$£ 2.50$ net

\section{The New Famillies}

YOUTH, COMMUNES, AND THE POLITICS OF DRUGS

ROSS V. SPEGK \& OTHERS

The authors-psychiatrists, psychologists, and anthropologistsvisited many American youth communes in an effort to understand what their members are trying to achieve. The result is a vivid and searching analysis of a growing social phenomenon whose implications for our future cannot be overestimated.

$$
£ 2.50 \text { net }
$$

Social Issues in the Seventies

\section{Meaning and Control}

ESSAYS IN SOCIAL ASPECTS OF SCIENCE AND TECHNOLOGY

Edited by D. O. EDGE \& J. N. WOLFE

This volume of essays-a selection of papers by sociologists, economists, and scientists-explores the social meaning of the emergence of modern science and technology and the consequent challenge to the processes of social control.
Studies in Social Ecology and Pathology

\section{The Wincroft Youth Project}

A SOCIAL-WORK PROGRAMME IN A SLUM AREA

GYRIL S. SMITH, M. R. FARRANT, \& H. J. MARGHANT

This description and evaluation of the efforts of a group of social workers to reach maladjusted boys in a slum area and help keep them out of trouble is an important contribution to the literature on action research and group work.

$£ 3.75$ net

\section{Regulating the Poor}

THE FUNCTIONS OF PUBLIC WELPARE

FRANCES FOX PIVEN \& RICHARD A. CLOWARD

This, the first full-scale analysis of the economic and political forces that control relief-giving in the USA, constitutes a radical critique of the institution of public welfare as a system for regulating the poor under Western capitalism.

$£ 3.75$ net

TAVISTOCK

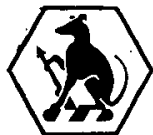




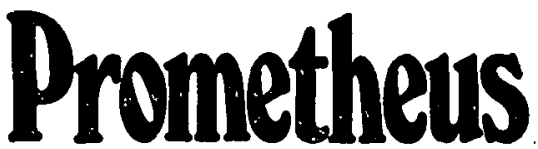

"... a new series of policy sfudies on knowledge in relation to human interests... a promising series of paperbacks." -THE NEW REPUBLIC

- The Bankruptcy of Academic Policy, edited by Philip C. Ritterbush

- Scientific Institutions of the Future, edited by Philip C. Ritterbusti

- Talent Waste: How Institutions of Learning Misdirect Human Resources, edited by Philip C. Ritterbush

An indispensable series for those responsible for the place and policy of institutions of learning in our society.

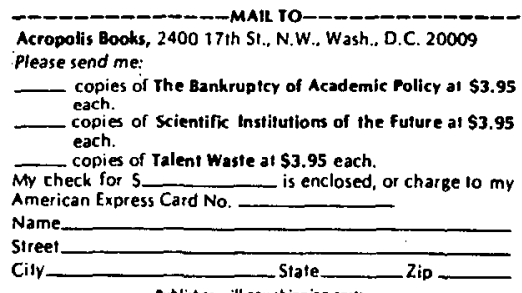

Mublisher will aur shipping costs.

\section{Journal of Social Policy}

is one of 48 learned journals published by Cambridge University Press.

A descriptive catalogue of Cambridge journals with details of back volumes is available from the London and New York offices of the Press.

Cambridge journals may be ordered from a bookseller or direct from the publishers.

\section{Cambridge University Press}

Bentley House, 200 Euston Road, London, NWI 2DB

American Branch:

32 East 57th Street, New York, N.Y. 10022 


\section{Journal of Social Policy}

NOTES FOR CONTRIBUTORS

1. All contributions and correspondence should be sent to: The Editor, Journal of Social Policy, The London School of Economics and Political Science, Houghton Street, Aldwych, London wC2A 2AE. All books for review should be sent to: The Review Editor, Journal of Social Policy, Department of Sociology, Goldsmiths' College, University of London, Lewisham Way, London SE14.

2. Articles should generally contain between 5,000 and 10,000 words including footnotes, although longer or shorter articles may be accepted by arrangement with the Editor. Short articles stand a better chance of early publication.

3. Submission of an article is taken to imply that it has not previously been published, or is not being considered for publication elsewhere. If an author is publishing a related article elsewhere, this fact should be stated.

4. Contributions (articles, review articles, reviews) should be clearly typed on one side of the paper only using a conventional size of paper, preferably A4. All material should be typed double-spaced with generous margins. Contributors should send two copies and keep one copy of the typescript for correcting proofs.

5. References to books and articles should include the following details: in the case of books, the full title and author or authors, place of publication, publisher and date; in the case of articles, the title and author or authors, full name of the journal, volume, year and page reference (first and last page). References and other footnotes should be numbered consecutively throughout and typed separately at the end of the article. Good articles which contain this bibliographical information will be accepted, even if they do not follow the journal's own arrangement of the information.

6. Tables should be clearly laid out and designed to fit on to a page $9 \frac{1}{4} \times 6 \frac{1}{4}$ inches. Vertical lines between columns should be omitted, and horizontal lines limited to the top and bottom of the table, with an additional one below the column headings. Totals and percentages should be labelled, and units identified.

7. Contributors are advised to look through earlier issues of the journal for guidance on points of general style.

8. First proofs may be read and corrected by contributors provided that they can give the editor an address through which they can be reached without delay and can guarantee to return the corrected proofs to the editor, by airmail where appropriate, within ten days of receiving them. The master proof will always be sent direct to the editor by the printer; contributors will receive duplicates.

9. Authors of articles and review articles (but not book reviews) receive twentyfive free offprints. Additional copies may be bought if ordered at proof stage.

10. Contributors of accepted articles will be asked to assign their copyright, on certain conditions, to Cambridge University Press, to help protect their material, particularly in the USA.

Cambridge University Press

Bentley House, 200 Euston Road, London NW1 2DB

American Branch : 32 East 57th Street, New York, N.Y. 10022

Single parts $£ 1.50$ net in UK ( $\$ 5.00$ in USA)

Annual subscription $£ 5$ net in UK ( $\$ 15.00$ in USA) 


\section{ARTICLES}

Merton C. BERNSTEIN: Private Pensions in the United States:

Gambling with Retirement Security

BERNARD BENJAMIN: Research Strategies in Social Service Departments of Local Authorities in Great Britain

NEIL GILBERT and HARRY SPECHT: 'Institutional Racism' and Educational Policy

A. LANDSBOROUGH THOMSON: Origin of the British Legislative Provision for Medical Research

\section{REVIEW ARTICLE}

BAR BARA N. RODGERS: Social Policy Implications of Britain's Entry into the Common Market

\section{BOOK REVIEWS}

Gillian Sutherland (ed.): Studies in the Growth of NineteenthCentury Government (José Harris)

FRANCES FOX PIVEN, RICHARD A. Clow ARD: Regulating the Poor: The Functions of Public Welfare (Morton S. Baratz) JON GOWER DAVIES: The Evangelistic Bureaucrat: A Study of a Planning Exercise in Newcastle upon Tyne (Maurice Broady) DEPARTMENT OF HEALTH AND SOCIAL SECURITY: Report of the Working Party on Medical Administrators (Margot Jefferys) ROY D. KING, NORMA V. RAYNES, JACK TIZARD: Patterns of Residential Care: Sociological Studies in Institutions for Handicapped Children (N. J. Smith)

ANTHONY FORDER (ed.): Penelope Hall's Social Services of England and Wales (Ian McArdle)

ROBERT W. KLENK, ROBERT M. Ryan: The Practice of Social Work (Anthony Forder)

EARL HOPPER (ed.): Readings in the Theory of Educational Systems (Tessa Blackstone)

MARTIN SILBERMAN, BRENDA CHAPMAN, IAN SINCLAIR, DAVID SNOW, ARYEH LEISSNER: Explorations in After-Care (J. P. Martin)

MARILYN TAYLOR: Study of the Juvenile Liaison Scheme in West Ham 1961-1965 (J. P. Martin)

JOAN ClEg (compiler): Dictionary of Social Services: Policy and

Practice (Anthony Forder)

PETER TOWNSEND, NICHOLAS BOSANQUET (eds): Labour and Inequality (Robert Holman)

M. DonAld HANCOCK, GIDEON SJoberg (eds): Politics in the PostWelfare State: Responses to the New Individualism (Paul Wilding) 